\title{
BUSINESS STRATEGIES FOR SUSTAINABILITY-MOTIVATED INNOVATION A Conceptual Framework
}

\author{
BERNARD AROGYASWAMY \\ Department of Management and Leadership, Madden School of Business \\ Le Moyne College \\ Syracuse, New York, U.S.A. \\ arogyas@lemoyne.edu
}

\begin{abstract}
Innovation has been and continues to be a key factor in the competitive advantage of business firms and economic growth of nations. However, while the creation of new offerings that are appealing to customers is central to corporate success, substantial negative outcomes may accompany or follow the unbridled pursuit of innovation. This paper investigates, among others, environmental damage and the diminution of social and political stability as problems arising from innovation and introduces a framework that may be used to enhance environmental and social sustainability through innovation. For the purposes of this study, innovation is viewed according to three types: product, process, and managerial. We also collapsed numerous sustainability strategies that have been identified in the literature into four categories: cost- and differentiation-based (environmental) and employee- versus communityoriented (social). The three innovation types are arrayed against the four sustainability strategies thereby yielding twelve approaches to innovating with sustainability in mind. Numerous examples are provided to illustrate how the framework is being or may be used. Such sustainability criteria can also serve vice-versa as drivers of organizational innovation.
\end{abstract}

\section{KEYWORDS}

corporate innovation; innovation types; environmental strategies; social sustainability; CSR strategies; sustainable innovation 


\section{INNOVATION AND ITS DISCONTENTS}

Defined as the creation of a new offering which has market appeal and results in the creation of wealth (OECD, 1997; Keeley, Pikkel, Quinn, \& Walters, 2013), innovation has been the basis for the economic success of numerous individuals and organizations as well as instrumental in the rise and prosperity of countries such as the United States (Tohidi \& Jabbari, 2012; Young, 2006). In this context, wealth includes financial profit as well as improved customer experience and additions to the store of knowledge (O'Sullivan \& Dooley, 2009; Thompson \& MacMillan, 2010).

In seeking new opportunities and driven by a passion to satisfy unfulfilled, emerging, or latent customer needs, the individual entrepreneur has often served as the seed from which large corporations have sprung (Ries, 2011; Meyer \& Crane, 2014). Firms such as Caterpillar, Thyssen, Honda, Hewlett Packard, Microsoft, Wedgwood, and Facebook started small, positioning themselves first on a slice of the productmarket-technology nexus and gradually expanding along one or more of those dimensions. Some compete by developing new products or applications (e.g., 3M, Sony, Apple) while others such as Unilever, Avon, and Harley-Davidson excel at building and retaining a core customer base as they adjust to the changing needs of the market (Hughes, 1986; Gordon, 2016). Nucor Steel achieved competitive advantage by making the manufacturing process and service more efficient (The Economist, 2001). Southwest Airlines and e-Bay developed a business model that offered a new value proposition to a specific market segment (Brelis, 2000; Osterwalder \& Pigneur, 2010).

Many of these storied corporations have demonstrated the ability to transition from being niche players to achieving dominance in an ecosystem. The key to their continued success, however, has almost always been their ability to innovate by increments and/or through industry-disruptive activities (Tushman \& O'Reilly, 1997; Christensen, 1997). Even once-dominant firms have made innovation of various types the centerpiece of their resurgence-General Motors had to react to new entrants with better products and lower prices in the 1980s (GM, 2014); Microsoft had to innovate when it was clear that near complete reliance on Windows and Office would lead to stasis or decline (The Economist, 2017).

The race to innovate, though, has a darker side despite its numerous benefits (e.g., increased longevity, speedier transportation, instant communications, and "on the go" entertainment). Looming resource constraints, spiking carbon emissions, widening inequalities, and declining social mobility have combined to threaten 
ecological and social sustainability and, as recent in-depth studies have astutely observed (Brill, 2018: 34-39; Stewart, 2018; Levitsky \& Ziblatt, 2018; Applebaum, 2018), are shaking even the very foundations of democracy and free market capitalism. We explore in this article some of the "negative spillovers" of innovation, particularly with regard to its impacts on environmental and social sustainability. However, we also cross-classify different types of innovation against various aspects of environmental and social sustainability to enable the development of strategies for "innovating with sustainability." One of the purposes underlying the proposed framework, therefore, is the amelioration or even avoidance of some of the problems arising from the race to innovate. Such a framework can serve as a guide for companies (and responsible executives) in developing fresh perspectives on enhancing sustainability. Researchers, on the other hand, can focus on the degree to which firms achieve sustainability through innovation and measure the effectiveness of such efforts. Comparative studies of corporate sustainability within and across industries can also prove to be particularly instructive. Finally, the interactive relationship between innovation and sustainability can also serve as a lens for analyzing cases particularly in business schools that place an emphasis on issues of social and environmental justice.

\section{SUSTAINABILITY OF THE INNOVATION-CONSUMPTION-GROWTH CYCLE}

The cycle created by the rising expectations of consumers, corporate and other societal innovation, and national economic expansion can be extremely beneficial but may also have damaging outcomes as mentioned earlier. Yet positive feedback (Arthur, 1996) between innovation and consumption seems to have become a part of people's mindsets in much of the modern world.

Customer pull and technology push mutually reinforce each other in driving corporate decisions toward producing goods and services (Schilling, 2017). The consumption-innovation cycle, without a doubt, has contributed to the economic growth of nations and the financial success of enterprises, yet it has also accelerated the rate of resource depletion, material wastage, and carbon emissions as well as incidences of income inequality and other factors that erode environmental and social sustainability. Consumption, sometimes verging on consumerism, also tends to reinforce values such as individualism, short-term thinking, and emphasis 
on local priorities, thereby weakening empathy, future orientation, and a global perspective, just as Pope Francis notes in Laudato Si' (2015). He is concerned that consumerism, which has contributed to rising levels of waste, carbon emissions, and resource depletion, has ravaged the planet, our common home. He appeals directly to consumers to moderate their needs, make do with less, and attach more importance to community, sharing, and reflection than to ownership and selforientation. Indeed, to shift our focus away from the "technocratic paradigm," Walker (2013) goes so far as to argue that spirituality should be the fourth dimension of sustainability in addition to economic, environmental, and ecological considerations, enabling us to design systems rather than products and thereby making us more reflective and less materialistic.

Pursuing economic growth based on the engine of innovation alone, therefore, has flaws and perils, some of which have been noted earlier. First, the rate of innovation has to accelerate in order for growth to continue. This, as one author puts it, may require developments as groundbreaking as the internet every decade or so on average (West, 2017). Second, numerous scholars have pointed out that output (GDP) and its growth as measures of economic wellbeing are flawed-not only does a measure like GDP include elements such as expenditures on crime, health care, remediation of environmental damage, etc., it also omits items such as work performed at home. Inequalities and social challenges posed by the pursuit of growth at all costs can thus obscure both limits to and drawbacks of growth (Phillips, 2006; Pissourios, 2013; Thiry, 2015). Indeed, alternative measures such as the Genuine Savings Index, the Sustainable Society Index, and the Human Development Indicator (Strezov, Evans, \& Evans, 2017) have been proposed yet a single dimension measure such as GDP remains most widely used due mainly to its simplicity and narrow focus on economic growth. In other words, innovation can both lead to the growth of firms and nations and be an indirect yet significant factor underlying rising disparities and the growing discontentment among large swathes of the population especially in the developed world (Rotman, 2014).

A third disadvantage to glorifying growth above all else is innovation that results in the replacement of millions of phones, TVs, cars, and appliances every year as this can cause a crisis in the disposal of used devices as well as shortages of, and cost increases in, the raw materials used (Ahmed, 2016). The danger posed by a continued rise in the use of fossil fuels and their resulting carbon emissions, coupled with the limited availability of water in many parts of the industrializing world, 
makes for a situation where continued growth into the foreseeable future appears to be unrealistic (Brown et al., 2011; West, 2017). Innovating in ways that address the harmful environmental and social effects of our current paradigm through designs that improve environmental and social sustainability is an effective means, therefore, by which to address the problems created by the market-technologygrowth cycle. We now explore some ways in which this can be done, starting with a review of some of the different types of innovation pursued by corporations.

\section{TYPES OF INNOVATION}

Innovation covers new products, processes, and management techniques and helps increase the availability, affordability, and variety of goods and services, thereby enabling firms to achieve a competitive advantage. There are many types of innovation, the best known being the development of radically new or incrementally different products and/or services (Schilling, 2017; Rothaermel, 2015). Once new offerings pique the interest of innovative consumers and succeed in attracting early adopters, process innovation is often called for to increase efficiencies, particularly if competition becomes more intense. Improving quality, lowering the cost of operations, raising throughput rates, and other such actions contribute to these efficiencies (Ettlie \& Reza, 1992; O'Sullivan \& Dooley, 2009). Other types of innovation acquire more competitive importance later on in the life cycle, including application-based innovation (finding new uses for existing products, e.g., doubling up mobile phones as cameras and navigation devices and extending the use of thin films from tapes to screen protectors, highway reflectors, and solar panels), marketing innovation (which includes finding new approaches to product delivery, e.g., Dell's direct-to-consumer strategy and Zara's decision to understock garments to create pent-up demand), and business model innovation (e.g., leasing in addition to sales, providing a free and a premium service, and using internet platforms to offer customized, low priced services) (Schilling, 2017; Moore, 2004; Keeley et al., 2013).

Creating an organizational climate in which new ideas are nurtured, shared, tested, and brought to market is often critical for maintaining an edge in innovation, especially in industries where user feedback is central to success. Termed managerial innovation, this capability, for instance, includes establishing suitable structures and processes by implementing decentralized, autonomous teams for new product development, fostering "hot spots" for informal interactions, and offering rewards 
for ideas that lead to successful new products. Creating a culture that tolerates dissent and encourages learning, the sharing of ideas, and the formation of social capital, among others (Gratton, 2007; Büschgens, Bausch, \& Balkin, 2013; Keeley et al., 2013), is also integral to managerial innovation. For the purposes of this paper, we shall organize innovation into three categories that encapsulate the entire gamut of innovation types: product, process, and managerial.

\section{SUSTAINABILITY STRATEGIES: ENVIRONMENTAL AND SOCIAL}

Epstein (2008), Blowfield and Murray (2014), and Bonini and Bové (2014), among others, note that numerous firms are beginning to view sustainability as being essential to future success. Laszlo and Zhexembayeva (2011) identify seven approaches for integrating environmental sustainability which range from compliance and lowering of costs to differentiation and raising of industry standards. Companies that are interested in pursuing more environmentally sustainable strategies typically progress along the "ladder of sustainability," beginning with a minimalist position of compliance or cost reduction before moving on to more ambitious efforts such as appealing to new markets (millennials, for example, who may be more concerned about environmental issues) or distinguishing themselves from their competition by offering refurbished, reusable, or remanufactured products, among others. For convenience, we categorize all environmental sustainability strategies as being either cost reduction- or differentiation-focused approaches.

With regard to social sustainability, we draw on the corporate social responsibility (CSR) literature. Most scholars and executives have come to accept, by and large, that while firms must be profitable to continue existing, they need to balance the search for ever-increasing returns with the continued wellbeing of both their stakeholders and the societies in which they operate (Moon, Crane, \& Matten, 2005; Swanson, 2008). There are a variety of frameworks for conceptualizing, and developing actionable ideas for, the social responsibility of companies. Among these models are Carroll's (1979) CSR pyramid, which consists of economic, legal, ethical, and discretionary purposes that are arranged hierarchically and with the top of the pyramid being where the firm decides how it can best add value to society; the stakeholder perspective, in which a corporation identifies ways it can optimize the satisfaction of all its main constituencies, recognizing that none of them may have all their expectations of the firm realized (Freeman, 2010); the triple bottom line, which, again, is a guide for 
achieving balance among economic, social, and environmental criteria (note that the latter is not explicitly included in the CSR pyramid and stakeholder perspectives) (Elkington, 1997); and Porter and Kramer's (2011) shared value approach, in which benefits to society are aligned with and arise from the firm's core competency, technology, or purpose, thereby contributing to the welfare of both the firm and society. It is worth mentioning that the shared value approach, though criticized at times for being self-serving with only incidental social benefits, can serve as a practical first step toward achieving a CSR commitment.

The arenas in which CSR efforts are deployed the most are the community, market, and employees. Community CSR includes support extended to causes in health, education, human rights, etc. Market CSR is directed toward reinforcing the firm's success by offering community support. Employee CSR focuses on improving working conditions (e.g., safety, child care, work-life balance), ensuring workers' rights (e.g., gender rights, freedom from discrimination), treating employees with respect, retraining them, and so on (Hess, Rogovsky, \& Dunfee, 2002; Caruana \& Crane, 2008; Moon, 2014). For this paper, we categorize social sustainability strategies as being either community- or employee-directed, with the market dimension folded into both of these groups. This speaks to the porous nature of the boundaries between groups (employees, for instance, may be integral to the success of efforts both in the community and in achieving a better market position).

\section{INNOVATION IN AND FOR SUSTAINABILITY}

Table 1 arrays types of innovation along the columns; sustainability occupies the rows. The columns are numbered while the rows have been assigned letters to simplify referencing any one of the twelve cells (e.g., C2 refers to Process Innovation which intends to achieve employee-related social sustainability). In much of what follows, we will discuss sustainability strategies that can be associated with each of the three types of innovation. In doing so, we will illustrate how prominent firms such as Pepsico, Manpower, 3M, and others fit into the InnovationSustainability matrix as well as how an organization can better align its approach to innovation with its sustainability focus. The intent of the table, then, is to tailor an organization's innovation strategy so it can enhance environmental and social sustainability and/or pursue sustainability initiatives which constitute new-tocompany or even new-to-world innovations. 


\begin{tabular}{|c|c|c|c|c|}
\hline & \multicolumn{3}{|c|}{ Innovation } \\
\hline & & 1. Product & 2. Process & 3. Managerial \\
\hline \multirow{2}{*}{ 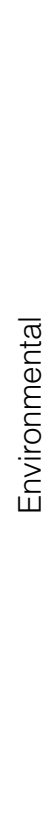 } & 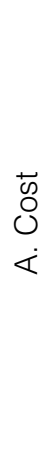 & $\begin{array}{l}\text { Redesign for reuse, } \\
\text { recycling; refurbish; } \\
\text { minimize consumer } \\
\text { and social lifecycle } \\
\text { costs; use of smart } \\
\text { devices; coordinate } \\
\text { with suppliers and } \\
\text { buyers }\end{array}$ & $\begin{array}{l}\text { Adopt lean operations, } \\
\text { redesign processes to } \\
\text { lower emissions and } \\
\text { material usage; supply } \\
\text { chain audits; use of } \\
\text { renewable energy; } \\
\text { minimize water use }\end{array}$ & $\begin{array}{l}\text { Vision and strategy } \\
\text { to initiate and expand } \\
\text { sustainability; } \\
\text { structured and organic } \\
\text { sharing; incentives } \\
\text { for lowering material/ } \\
\text { energy usage; culture } \\
\text { of frugal thinking; } \\
\text { persuasion of } \\
\text { shareholders }\end{array}$ \\
\hline & 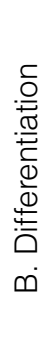 & $\begin{array}{l}\text { Enhancing customer } \\
\text { value-educating } \\
\text { customers about } \\
\text { sustainability, energy } \\
\text { saving appliances and } \\
\text { consumables, locally- } \\
\text { grown produce, etc.; } \\
\text { application innovation }\end{array}$ & $\begin{array}{l}\text { Use of non-toxic, } \\
\text { low-waste materials } \\
\text { in non-durables and } \\
\text { packaging; use of } \\
\text { lighter materials; } \\
\text { minimize post- } \\
\text { consumer waste }\end{array}$ & $\begin{array}{l}\text { Transition from cost- } \\
\text { based to differential } \\
\text { sustainability; } \\
\text { align capability, } \\
\text { performance, and } \\
\text { reputation }\end{array}$ \\
\hline \multirow[t]{2}{*}{$\begin{array}{l}\overline{\frac{\pi}{U}} \\
\text { D } \\
\infty\end{array}$} & 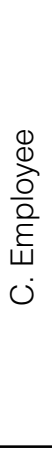 & $\begin{array}{l}\text { Employee involvement } \\
\text { in generating ideas } \\
\text { that serve a higher } \\
\text { purpose (healthier } \\
\text { food products; serving } \\
\text { low-income buyers; } \\
\text { working with schools, } \\
\text { charities, the arts; } \\
\text { partnering with social } \\
\text { enterprise) } \\
\end{array}$ & $\begin{array}{l}\text { Facilitate involvement } \\
\text { of employees who } \\
\text { are passionate } \\
\text { about social causes; } \\
\text { establish mechanisms } \\
\text { and informal } \\
\text { procedures }\end{array}$ & $\begin{array}{l}\text { Management's } \\
\text { example in giving } \\
\text { voice to workers, } \\
\text { reducing disparities } \\
\text { and biases; being } \\
\text { proactive in retraining } \\
\text { workers whose jobs } \\
\text { may be displaced by } \\
\text { technology, trade, and } \\
\text { shifting demand } \\
\end{array}$ \\
\hline & 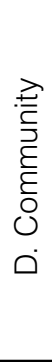 & $\begin{array}{l}\text { Designing products } \\
\text { to serve the poor } \\
\text { (health care, sanitation, } \\
\text { energy); bottom-of- } \\
\text { pyramid; partnering } \\
\text { with NGOs, SEs for } \\
\text { more effective delivery }\end{array}$ & $\begin{array}{l}\text { Create supportive } \\
\text { ecosystem through } \\
\text { partnerships with } \\
\text { local organizations; } \\
\text { skill training; scale up } \\
\text { services for the poor }\end{array}$ & $\begin{array}{l}\text { Develop long- } \\
\text { term sustainability } \\
\text { strategies that align } \\
\text { societal need, firm } \\
\text { competence, and } \\
\text { employee interest; } \\
\text { engage shareholders } \\
\text { in these efforts }\end{array}$ \\
\hline
\end{tabular}

Table 1: Strategies for innovation in sustainability innovation. 


\section{ENVIRONMENTAL SUSTAINABILITY: COST REDUCTION}

We begin with environmental sustainability strategies (top-left in Table 1). Lowering internal costs to achieve cost leadership (Porter, 1985) may benefit a firm but may come at the expense of the environment in the form of increased carbon emissions, usage of harmful materials, higher after-sales and post-consumer waste, and so on. We thus contend that social and consumers' life cycle costs (Amienyo, Doyle, Gerola, Santacatterina, \& Azapagic, 2016), in addition to the costs incurred by the firm, need to be addressed. The environmental impact (A1 in Table 1) may be minimized while reducing costs by refurbishing products (e.g., laptops, phones) so that these can be reused; remanufacturing (e.g., cars) by replacing worn out parts; reusing (e.g., sending used clothing to poorer areas of the country or the world); and redesigning (as has already been done to some mobile phone models) for easier separation of recyclable parts (Nguyen, Stuchtey, \& Zils, 2014; Reike, Vermeulen, $\&$ Witjes, 2018). Redesign may also increase sales and profits-General Electric, for instance, reduced the cost and price of ultrasound equipment by about $80 \%$ after reconfiguring it to cater to the needs of low-income countries. The firm then reworked the device further to make it portable at an even lower cost (Immelt, Govindarajan, \& Trimble, 2009).

Lowering environmental costs to society would also be included in A1. An example would be dishwashers that require less water at lower temperatures, are more energy-efficient, and use detergents that do not result in pollution-while such products might cost more to purchase, their lifecycle costs to consumers and to society at large may turn out to be way below those of less expensive models. The expanding reach of the Internet of Things (in smart metering as well as home control devices such as the Nest) is another way-through it, product innovation helps reduce resource and energy use in society as a whole, making it a step in the direction of greater sustainability (Hargadon, 2015; Arias, Lueth, \& Rastogi, 2018).

One of the more common strategies adopted by firms seeking cost leadership is attaining greater efficiencies through process innovation (A2), with investing in process $R \& D$ and lean manufacturing along with extracting increased efficiencies from the supply chain being some of the more frequently used approaches (The Economist, 2013). Environmental process innovation, however, goes beyond traditional approaches by targeting quantity and type of resource inputs used. Examples of strategies in this cell of the table are Interface's modular (floor) carpets, 
which enable the replacement of only those segments with high-traffic (Anderson, 2009), and Novelis Aluminum's sharply diminished water consumption combined with its high aluminum recycling rate (Novelis, 2017).

Managerial innovation in A3 covers a wide range of actions by which organizations stimulate creativity. Examples include teams both formed by management and that arise organically (for developing new products and/ or reducing wastage, for example) as well as the institution of mechanisms for sharing knowledge that involves similar technologies across the organization to achieve both economies of scale and scope. The intent of 3M's Technical Forums, for instance, is to share technologies across divisions. These periodic events ensure that sustainability in various forms gains widespread commitment as the firm embarks on a strategy of innovation for sustainability (Gunther, Adamo, \& Feldman, 2010). As O'Sullivan and Dooley (2009) note, managerial innovation also includes investing in research and development to reduce lifecycle costs and wastage of materials during manufacture (thus facilitating A1 and A2), fostering a culture of sustainability by offering incentives (providing internal capital, for instance, to invest in employee-generated ideas with market potential), and leaders setting an example. A configuration of coordinated decentralization would thus help in generating new ideas which are then examined and disseminated. General Electric's Ecomagination group, for instance, was formed after it was revealed that various divisions were undertaking sustainability initiatives without sharing or leveraging new ideas. The group helped coordinate the company's diverse efforts toward deepening focus on sustainability and improving time to market (Chesbrough, 2012).

Managerial innovation, in terms of charting a direction (e.g., technology leadership versus followership) and with regard to initiatives (R\&D-driven, market-driven, open innovation, benchmarking, building absorptive capacity, wide employee involvement), can not only determine how organizations may be best configured for innovation but also facilitate the pursuit of other types of innovation. As Camisón and Villar-López (2014) and Damanpour and Aravind (2012) stress, managerial innovation can be the driving force behind a firm's ability to develop new products/services, processes, applications, business models, and marketing approaches. 
A word of caution: total costs for the firm may rise in the short term while environmental costs to consumers and to society at large are being reduced. It is possible, however, to lower even short-term costs if, as an article in Crespin (2012) notes, the initial focus is on the source of the bulk of emissions and/or of material usage (such as the supply chain).

\section{ENVIRONMENTAL STRATEGIES: DIFFERENTIATION}

Environmental differentiation strategies are designed to deliver value through sustainable solutions that appeal to customers even at higher prices. Examples of strategies in B1 are roof tiles that double as solar panels, restaurants that make use of vegetables which lack aesthetic appeal but not nutritional value, grocery stores that source organically grown food from local suppliers, windows and doors that reduce heating and cooling costs, and cars that are carbon neutral (e.g., electric) with complementary features (such as nationwide charging stations). Given that the success of differentiation strategies depends upon enhanced value as perceived by the user (consumer surplus), purveyors of such approaches also need to position sustainability as a key differentiator and employ a combination of facts, transparency, and certification to ensure that customers get the message ("educating" the customer) (Himmelfarb, 2015).

Pepsico's "Performance with Purpose" vision (Marcus, 2015: 237-240), in which the company embarked on a strategy aimed at developing healthier snacks and beverages, was intended to create a distinctive edge for the firm while anticipating possible regulatory action in the future even if it meant higher costs and lower margins in the short term. Henkel introduced enzymes into its detergent in an effort to lower water temperatures for laundry machines, thereby helping users reduce their energy and water bills. The firm's elimination of phosphates also helped minimize impact on aquifers (Loew, Clausen, Hall, Loft, \& Braun, 2009). H\&M's and Zara's sourcing of organic cotton from South Asia helps enhance sustainability while promoting the welfare of farmers, thereby differentiating these firms from their competitors (Emmanuel, 2015). Firms whose products are recyclable once their useful life is over and used as inputs for new products in a cradle-to-cradle cycle (Braungart \& McDonough, 2002) are also positioned as environmental differentiators. 
B1 is also home to application innovation or the search for new and alternative uses for already existing products and technologies, such as using electric cars to power buildings during those parts of the day when energy is expensive. Companies that use the same material for making a diverse range of products also employ this approach to innovation. They are able to innovate around a core technology, thereby minimizing wastage while building a reputation (e.g., W. L. Gore in fabrics, boots, and temperature-resistant industrial materials [Hobcraft, 2011]). The use of plastic bags and bottles in road-building, for instance, exemplifies this kind of innovation in sustainable application.

Process innovation can enhance sustainability by changing how a product is made or how a service is delivered (B2). It goes beyond lean operations in emphasizing sustainability for all stages of the life cycle (including the supply chain and post-sale phases). Interface's elimination of harmful chemicals in carpets (Thorpe, 2014), Henkel's similar action for detergents (Loew et al., 2009), and the substitution of aluminum for steel in car bodies to reduce their weight and improve gas mileage (Novelis, 2017) are among the ways differentiation in sustainability is being implemented through process innovation.

Managerial innovation (B3) also embeds sustainability as a differentiating factor. Setting a strategic direction and vision for the firm's stance on product innovation (e.g., industry leader, quick follower, low cost imitator) and following that up with resource allocation (investing in product $R \& D$, creating social capital, fostering grassroots commitment to sustainable actions) are integral to managing new ideas for sustainability. Whole Foods, for instance, established standards for organic food that exceeded industry benchmarks (in part by banning nearly eighty ingredients from its shelves) while attempting to source more local produce (McLaughlin \& Martin, 2009; Marcus, 2015: 284-286). For firms like 3M, supporting and funding viable ideas in an open atmosphere where new opportunities and solutions are constantly being sought is one way to facilitate and enable more innovative efforts in general and more recently in sustainability. Resource and emission constraints, among other factors, are integral to 3M's innovation strategies. The firm sets ambitious goals that encompass the usage of sustainable materials as well as the reduction of carbon emissions and water usage while helping customers optimize resource inputs and energy expended (3M, 2018). 
For a firm seeking to stake out a competitive advantage in sustainability, the message has to be clear that the company values sustainable action as the best approach for satisfying critical stakeholders such as customers, shareholders, suppliers, and employees. Moreover, in case some stakeholders like customers and shareholders are reluctant to accept the need for and value of such a strategic trajectory, part of the managerial innovation process lies, as Mackey and Sisodia (2013) suggest, in persuading these constituents about the long-term benefits of a sustainable strategy (e.g., decreased lifecycle costs, health benefits, etc. for customers; avoidance of future risks, likelihood of higher profits after an initial spike in costs, etc. for shareholders). This is especially important in countries where regulations concerning environmental issues are not so stringent or are being dismantled. Obtaining the buy-in of critical stakeholders, particularly customers, shareholders, and employees, is as important as adopting environmentally-friendly initiatives. As is the case with creating a distinctive position through any competency (quality, lead time, safety, etc.), the perception created in the minds of relevant stakeholders can spell the difference between success and failure in sustainable innovation. Thus, while establishing a reputation for sustainability can help create an enduring competitive advantage, achieving a balance between reputation and true capability calls for managerial ingenuity. Indeed, as Marcus (2015: 286-292) notes, Walmart's success in getting dairy farmers to switch to low carbon feed for cattle and use methane digesters and in installing wind turbines and LED lighting (at considerable additional cost) speaks of a commitment to sustainable solutions that is communicated to its major stakeholders through its actions.

\section{SOCIAL SUSTAINABILITY AND PRODUCT INNOVATION}

In this section, we investigate how product innovation can be aligned with a firm's social sustainability (SS) strategies with regard to community and employees. Product innovation is instrumental in SS (C1, D1 in Table 1) when restaurants, for instance, recast their menus and recipes to incorporate locally-grown produce, thereby reaping environmental benefits while increasing the freshness and creativity of their offerings. Regional farmers and markets, in addition, also benefit from such actions (Mealey, 2018). Other efforts that lie at the nexus of product development and SS strategies (Radjou, Prabhu, \& Ahuja, 2012) include Osram's (Loew et al., 2009) development of solar lamps for use in villages that lack electricity, General Electric's 
redesigning of medical diagnostic equipment (cited earlier) to accommodate the budgets of poorer nations, and the use of "frugal engineering" (designing products from the ground up to make them more affordable for lower income segments of all societies).

Businesses that extend their product range into the social arena (such as commercial banks that enter the market for microcredit) and companies that develop products aimed at lower income populations are also combining market/community sustainability with product innovation. Included in the latter are bottom-ofthe-pyramid strategies (which generate high volume, low margin sales) such as Hindustan Lever's effort aimed at reducing the incidence of diarrhea by developing and marketing affordable soaps for millions of low income families (Prahalad, 2005: 207-239). Pharmaceutical firms developing drugs to help vulnerable people even at the expense of profits (Boseley, 2012) is a relatively recent phenomenon exemplifying this approach to sustainability in the social sphere. Alliances with non-governmental organizations (NGOs) and social entrepreneurships (SEs) may also weave SS into the innovation fabric of corporations-examples include firms like Pfizer that sponsor SEs seeking to address imbalances in society in areas like sanitation $(\mathrm{Ng}, 2017)$ and other matters affecting the most vulnerable populations (e.g., food security, water scarcity, and climate disasters [Acumen, 2015]).

Employee involvement can also leverage delivery of social value to other stakeholders. In the product innovation examples cited earlier, for example, employee participation in developing and popularizing healthier snacks and drinks, implementing microcredit, working with schools, building homes, and delivering food to the homeless can enhance both program effectiveness as well as employee commitment and loyalty (Kim \& Scullion, 2013). Employees may also be involved in the development of new products from which profits are used to provide loans for low income clients and invest in social enterprises, as is the case with Barclay's Social Innovation Facility (Barclays, n.d.).

\section{SOCIAL SUSTAINABILITY AND PROCESS INNOVATION}

In terms of increasing worker satisfaction and efficiency, SS initiatives can also be a part of process innovation (C2) especially when employees are active participants in making refurbishment, remanufacturing, and reuse strategies 
function properly, as shown by Norton et al (2015). This would also bolster process innovation undertaken as part of environmental initiatives (A2). Giving employees a greater say in workplace decisions not only enhances employee commitment but also improves productivity.

With regard to process innovation for community-related initiatives, working with local entrepreneurs to develop network effects for emerging products (such as repairing wind farms or electric vehicles) is one way to enlist creative partners as well as foster community ecosystems (D2). Examples of corporate efforts to enlist process innovation in the service of society are companies engaged in fair trade practices such as Starbucks (Horovitz, 2015) and supermarkets sourcing locally grown produce (Whole Foods [Dewey, 2017]) as well as firms working to help communities that are experiencing employment reduction and/or a shortage of skills, as some of the technology giants are attempting to do (Upson, 2018). The Aravind Eye Hospital, established in Madurai, India, adopted a novel approach to putting process innovation to work in helping patients in danger of losing their eyesight. Having developed a process for needed surgery that enabled them to lower costs, the founders are able to provide free services to the poor that are subsidized by charging higher income individuals. The development of an intraocular lens at a fraction of the market price also bolstered their ability to help the indigent even further (Munshi, 2009: 34-52).

\section{SOCIAL SUSTAINABILITY AND MANAGERIAL INNOVATION}

Managerial ingenuity is critical to establishing a socially sustainable strategy $(\mathrm{C} 3, \mathrm{D} 3)$ and keeping it in place over the long term. Consider Manpower, Inc., a Fortune 500 multinational engaged in finding skilled workers for companies across the globe. When a tsunami devastated parts of southern India in 2004, numerous firms offered to support relief efforts by providing funds to private- and governmentrun agencies. Manpower, however, launched its own initiative. It set up a facility in the heart of the devastated area with the goal of training people in skills that were needed in that part of the country and beyond. Trainers were recruited and given flexibility to decide which trades were most in demand. An alliance was formed with an NGO that had experience in the region, with local customs, and with the government. People received training for a number of occupations such as computer and cell phone repair, masonry, construction, and woodworking. Many 
women enrolled, and it was the first time the majority of them had ever worked outside the home. Some of the products were offered for sale at the center (the goal being to make the centers self-supporting in three years) and trainees were often placed with Manpower's regular clients for whom the reputation of the firm was greatly enhanced. Moreover, a group of Manpower employees, including the regional manager, were involved with this endeavor which served to internalize the company's mission (Arogyaswamy \& Elmer, 2010). As such, while Manpower was not entirely altruistic in this venture, it was being a good citizen by bringing the benefits of work and life skills to people in despair. It effectively embellished its reputation with local governments and its client base while offering its employees a sense of purpose higher than that of simply making more profit.

This formulation of a social sustainability strategy in which market, community wellbeing, and employee ideals converge is not uncommon. As detailed in IBM's (2018) Citizenship Report, for instance, IBM Health Corps works with health organizations using analytics and cognitive science to improve delivery of medical care, Safety Net provides IBM solutions for civic organizations, and P-tech helps veterans with software training. Unilever's Sustainable Living Plan, aimed at countering climate change as well as addressing social inequalities and the need to tackle poverty, is also a striking example of how corporate vision can guide innovation. It has been reported (Sustainable Brands, 2018) that brands integral to Unilever's Plan have become central to the firm's success, growing much faster than the rest of their products.

\section{CONCLUSION}

We have posited and argued, along with providing examples, in the preceding sections that corporations need to integrate ecological and social sustainability in their strategies as part of building a competitive advantage through innovation. One way to do so could be by identifying the type of innovation that best suits their needs. Herman Miller, for instance, a firm that was already invested in lean manufacturing, developed a focus on sustainability through process innovation (A2) by using recycled materials as inputs and building reusability into its finished products. The company eventually differentiated itself on that basis (B2) and transitioned to product innovation with a view toward differentiation (B1) by introducing a new line of accessories, furniture for home offices, illumination, and 
so on while working with architects and interior decorators (Kackley, 2015; Herman Miller, 2018). Starting with a commitment to redesign products, extend their useful lives, and minimize total life cycle costs to consumers and society (A1) can thus help firms with no history of sustainability strategies achieve initial acceptance. Process enhancements (A2) may also facilitate such a transition.

The role of managerial innovation is critical in terms of providing a sense of direction, stimulating product and process innovation, motivating employees, and creating a culture and organizational configuration that is supportive of innovation focused on sustainability. It is well known that working toward a purpose higher than their own needs and the firm's material goals often inspires employees (Kim \& Scullion, 2013). Initiatives toward sustainability in both its environmental and social forms could thus provide such a purpose if the company's actions are demonstrative of its stated intent.

Product and process innovation, however, lead inexorably to new technologies that often disrupt the workplace by requiring skill-sets radically different from the ones that some or many existing workers already possess. In such cases, we argue that it is incumbent on firms that are committed to social sustainability to take responsibility for the workplace security and on-the-job fulfilment of these employees. For instance, firms should not only develop strategies for profiting from market opportunities as new forms of product and process technology make their appearance. They should also consider simultaneously formulating plans for re-training employees to transition to the new technology. Indeed, relying on the free market or governments to take care of displaced workers as new methods are developed to increase productivity in the workplace (e.g., through automation and robotics) has, by and large, been less than adequate (Fadulu, 2018). It is time for corporations to play an expanded role in dealing with the changes sweeping society, changes which they have a played a leading role in bringing about. Microsoft (Microsoft News Center, 2017) has taken a step in this direction by forming an alliance with the Markle Foundation and investing \$25.8 million to help workers acquire the digital skills they will need in the workplace of the future. The Royal Bank of Canada, meanwhile, has invested over $\$ 500$ million in a multiyear project to prepare youth for the world of work in 2025. Involving young people to envision what they need to prepare for and using metrics to assess the accuracy of predictions and effectiveness of action plans (RBC, n.d.) are among the features of this initiative. 
Other companies such as AT\&T, Apple, Google, and IBM (as noted earlier) have also launched similar initiatives which stand at the confluence of the community-, employee-, and market-driven approaches to social sustainability. Consider AT\&T's approach to this challenge: it is investing $\$ 1$ billion to launch a massive retraining program after discovering that nearly half of its 250,000 employees lacked the necessary competencies to meet the company's digital needs over the next decade (and that many specializing in hardware would become redundant). While the rationale underlying this strategy is partly because training new employees would cost more, the main reason appears to be that a long-term, ongoing relationship with its own workforce would bolster morale and foster mutual loyalty (Caminiti, 2018).

Thus, while measures for both sustainability and innovation are needed to substantiate the connections hypothesized in this paper, the conceptual and normative approach adopted herein can be gainfully leveraged for conducting empirical work along the lines proposed. Considerable studies in the area of sustainability metrics have already been done by researchers such as Keeble, Topiol, and Berkeley (2003), Pissourios (2013), and Arogyaswamy (2018). The types of innovation delineated here, moreover, could be operationalized based on the works of authors such as Adams, Bessant, and Phelps (2006) and Alegre, Lapiedra, and Chiva (2006). Indeed, while some connections (e.g., cost reduction-environmental sustainability) might be relatively easier to establish compared to others (e.g., community sustainability-product innovation), the benefits in terms of lower emissions and material wastage as well as enhanced employee and community welfare can be tremendous.

We conclude with the observation that future repercussions of unrestrained innovation could be even more damaging. Husain (2017) notes that the nature and availability of work will shift radically as Artificial Narrow Intelligence based on deep learning (focused on goals set by humans such as the proliferation of drone deliveries, autonomous cars, and automated stock trading) becomes a taken-forgranted part of our lives. The social, cultural, and political impacts of innovations in the near term are likely to rival the environmental impact, concerns over which have already elicited widespread alarm and received wide publicity. The prospect of international cooperation, for instance, is likely to erode as more countries begin pursuing nationalist agendas, thereby fueling a race for accelerated growth driven by innovation. As Worthington (2018), Cederman (2019), and others have pointed 
out, a rising tide of nationalist passion can result in the jeopardization of concerns for the environment, of pressing social needs, and of the observance of political norms. The need for corporations to act, which has been emphasized in this paper, has become even more imperative. Collaboration with governments, NGOs, and other civic institutions is required without a doubt for addressing the multiple threats posed by the acceleration of innovation to fuel economic growth. As the main driver of economic growth and change, however, the business firm may need to spearhead the effort to keep society on an even keel.

\section{REFERENCES}

3M. 2018. 2018 sustainability report: Improving lives. Available at https:// multimedia.3m.com/mws/media/1542803O/2018-sustainability-report.pdf.

Acumen. 2015. Social enterprises and global corporations: Collaborating for growth with impact. Available at https://acumen.org/wp-content/ uploads/2015/10/1502_AcumenSummitReport_092115Finalv2_pgs.pdf.

Adams, R., Bessant, J., \& Phelps, R. 2006. Innovation management measurement: A review. International Journal of Management Reviews, 8(1): 21-47.

Ahmed, S. 2016. The global cost of electronic waste. The Atlantic, Sep. 29.

Alegre, J., Lapiedra, R., \& Chiva, R. 2006. A measurement scale for product innovation performance. European Journal of Innovation Management, 9(4): 333-346.

Amienyo, D., Doyle, J., Gerola, D., Santacatterina, G., \& Azapagic, A. 2016. Sustainable manufacturing of consumer appliances: Reducing life cycle environmental impacts and costs of domestic ovens. Sustainable Production and Consumption, 6: 67-76.

Anderson, C. 2009. Confessions of a radical industrialist. New York: St. Martin's Press.

Applebaum, A. 2018. A warning from Europe: The worst is yet to come. The Atlantic, October. 
Arias, R., Lueth, K., \& Rastogi, A. 2018. The effect of the Internet of Things on sustainability. World Economic Forum. Available at https://www.weforum. org/agenda/2018/01/effect-technology-sustainability-sdgs-internet-things-iot/.

Arogyaswamy, B. 2018. Sustainability metrics: A time-based multilevel framework. Journal of Strategic Innovation and Sustainability, 13(2): 71-82.

Arogyaswamy, B., \& Elmer, W. 2010. Corporate social entrepreneurship: Concepts and a case study. Journal of International Business Education, 5: 29-42.

Arthur, B. 1996. Increasing returns and the new world of business. Harvard Business Review, 74(4): 100-109.

Barclays. n.d. Social innovation. Available at https://www.home.barclays/citizenship/ access-to-financing/social-innovation.html.

Blowfield, M., \& Murray, A. 2014. Corporate responsibility. Oxford: Oxford University Press.

Bonini, S., \& Bové, A-T. 2014. Sustainability's strategic worth. Boston, MA: McKinsey.

Boseley, S. 2012. Big Pharma ups its game in providing drugs to people in poor countries. Available at https://www.theguardian.com/global-development/2012/ nov/28/big-pharma-drugs-poor-countries.

Braungart, M., \& McDonough, W. 2002. Cradle to cradle: Remaking the way we make things. New York: Farrar, Straus and Giroux.

Brelis, M. 2000. Simple strategy makes Southwest a model for success. Boston Globe, Nov. 5.

Brill, S. 2018. How my generation broke America. Time, May 26.

Brown, J., Burnside, W., Davidson, A., DeLong, J., Dunn, W., Hamilton, M., MercadoSilva, N., Nekola, J., Okie, J., Woodruff, W., \& Zuo, W. 2011. Energetic limits to economic growth. Bioscience, 61(1): 19-26. 
Büschgens, T., Bausch, A., \& Balkin, D. 2013. Organizational culture and innovation: A meta-analytic review. Journal of Product Innovation Management, 30(4): 763-781.

Caminiti, S. 2018. AT\&T's \$1 billion gambit: Retraining nearly half its workforce for jobs of the future. Available at https://www.cnbc.com/2018/03/13/atts-1billion-gambit-retraining-nearly-half-its-workforce.html.

Camisón, C., \& Villar-López, A. 2014. Organizational innovation as an enabler of technological innovation capabilities and firm performance. Journal of Business Research, 67(1): 2891-2902.

Carroll, A. 1979. A three-dimensional conceptual model of corporate performance. Academy of Management Review, 4(4): 497-505.

Caruana, R., \& Crane, A. 2008. Constructing consumer responsibility: Exploring the role of corporate communications. Organization Studies, 29(12): 1495-1519.

Cederman, L. 2019. Blood for soil: The fatal temptations of ethnic politics. Foreign Affairs, 98(2): 61-68.

Chesbrough, H. 2012. GE's Ecomagination challenge: An experiment in open innovation. California Management Review, 54(3): 140-154.

Christensen, C. 1997. The innovator's dilemma: When new technologies cause great firms to fail. Boston, MA: Harvard Business School Press.

Crespin, R. 2012. If sustainability costs you more, you're doing it wrong. Forbes/The CSR Blog, Aug. 13. Available at https://www.forbes.com/sites/csr/2012/08/13/ifsustainability-costs-you-more-youre-doing-it-wrong/\#4709051428d9.

Damanpour, F., \& Aravind, D. 2012. Managerial innovation: Conceptions, processes and antecedents. Management and Organization Review, 8(2): 423-454.

Dewey, C. 2017. The big consequences of the Amazon-Whole Foods deal no one's talking about. Washington Post, June 30. 
Elkington, J. 1997. Cannibals with forks: The triple bottom line of 21st century business. New York: Capstone.

Emmanuel, A. 2015. The ethics of fast fashion: H\&M and Zara. Available at https:// goodonyou.eco/the-ethics-of-fast-fashion-hm-and-zara/.

Epstein, M. 2008. Making sustainability work: Best practices in managing and measuring corporate social, environmental and economic impacts. Sheffield, UK: Greenleaf.

Ettlie, J., \& Reza, E. 1992. Organizational integration and process innovation. Academy of Management Journal, 35(4): 795-827.

Fadulu, L. 2018. Why is the U.S. so bad at worker retraining? The Atlantic, Jan. 4.

Francis. 2015. Laudato si': On care for our common home. Available at http://w2.vatican.va/content/francesco/en/encyclicals/documents/papafrancesco_20150524_enciclica-laudato-si.html.

Freeman, R. 2010. Strategic management: A stakeholder approach. Cambridge: Cambridge University Press.

GM. 2014. GM outlines strategic plan. Available at https://media.gm.com/Pages/ news/us/en/2014/Oct/1001-gm-plan.html.

Gordon, R. 2016. The rise and fall of American growth: The U.S. standard of living since the Civil War. Princeton, NJ: Princeton University Press.

Gratton, L. 2007. Hot spots: Why some teams, workplaces, and organizations buzz with energy-and others don't. San Francisco: Berrett-Koehler Publishers.

Gunther, M., Adamo, M., \& Feldman, B. 2010. 3M's innovation revival. Fortune 500, Sep. 24.

Hargadon, A. 2015. Sustainable innovation: Build your company's capacity to change the world. Stanford, CA: Stanford University Press. 
Herman Miller. 2018. Designing for the future: Herman Miller better world report 2018. Available at https://www.hermanmiller.com/content/dam/hermanmiller/ documents/a_better_world/Better_World_Report.pdf.

Hess, D., Rogovsky, N., \& Dunfee, T. 2002. The next wave of corporate community involvement: Corporate social initiatives. California Management Review, 44(2): 110-125.

Himmelfarb, N. 2015. Know these three Vs of sustainability communication. Greenbiz. Available at https://www.greenbiz.com/article/know-these-three-vssustainability-communication.

Hobcraft, P. 2011. Understanding innovation the W L Gore way. Innovation Excellence. Available at https://www.innovationexcellence.com/ blog/2011/09/28/understanding-innovation-the-w-l-gore-way/.

Horovitz, B. 2015. Starbucks: 99\% ethically sourced java. USA Today, April 10.

Hughes, J. 1986. The vital few: The entrepreneur and American economic progress. New York: Oxford University Press.

Husain, A. 2017. The sentient machine: The coming age of artificial intelligence. New York: Simon and Schuster.

IBM. 2018. Citizenship: Bringing smart to life. Available at https://www.ibm.com/ $\mathrm{ibm/responsibility/2017/assets/downloads/IBM-2017-CRR-Citizenship.pdf.}$

Immelt, J., Govindarajan, V., \& Trimble, C. 2009. How GE is disrupting itself. Harvard Business Review, 87(10): 56-65.

Kackley, R. 2015. Herman Miller builds a sustainability model. Crain's Detroit Business, Aug. 9

Keeble, J., Topiol, S., \& Berkeley, S. 2003. Using indicators to measure sustainability performance at a corporate and project level. Journal of Business Ethics, 44(2-3): 149-158. 
Keeley, L., Pikkel, R., Quinn, B., \& Walters, H. 2013. Ten types of innovation: The discipline of building breakthroughs. Hoboken, NJ: Wiley.

Kim, C., \& Scullion, H. 2013. The effect of corporate social responsibility (CSR) on employee motivation: A cross-national study. The Poznan University of Economics Review, 13(2): 5-30.

Laszlo, C., \& Zhexembayeva, N. 2011. Embedded sustainability: The next big competitive advantage. Stanford, CA: Stanford University Press.

Levitsky, S., \& Ziblatt, D. 2018. How democracies die. New York: Crown Publishing. Loew, T., Clausen, J., Hall, M., Loft, L., \& Braun, S. 2009. Case studies on CSR and innovation: Company cases from Germany and the USA. Berlin: Institute for Sustainability.

Mackey, J., \& Sisodia, R. 2013. Conscious capitalism: Liberating the heroic spirit of business. Boston, MA: Harvard Business Review Press.

Marcus, A. 2015. Innovations in sustainability: Fuel and food. Cambridge: Cambridge University Press.

McLaughlin, K., \& Martin, T. 2009. As sales slip, Whole Foods tries health push. The Wall Street Journal, Aug. 5.

Mealey, L. 2018. Benefits of restaurants serving local food. The Balance-Small Business. Available at https://www.thebalancesmb.com/ten-reasons-restaurantsshould-buy-local-foods-2888595.

Meyer, M., \& Crane, F. 2014. New venture creation: An innovator's guide to entrepreneurship. Thousand Oaks, CA: Sage Publications.

Microsoft News Center. 2017. The Markle Foundation and Microsoft partner to accelerate a skills-based labor market for the digital economy. Available at https://news.microsoft.com/2017/06/27/the-markle-foundation-and-microsoftpartner-to-accelerate-a-skills-based-labor-market-for-the-digital-economy/. 
Moon, J. 2014. Corporate social responsibility: A very short introduction. Oxford: Oxford University Press.

Moon, J., Crane, A., \& Matten, D. 2005. Can corporations be citizens? Corporate citizenship as a metaphor for business participation in society. Business Ethics Quarterly, 15(3): 429-453.

Moore, G. 2004. Darwin and the demon: Innovating within established enterprises. Harvard Business Review, 82(7-8): 86-92.

Munshi, P. 2009. Making breakthrough innovation happen: How eleven Indians pulled off the impossible. New Delhi: Collins.

$\mathrm{Ng}$, A. 2017. Models of high-level partnerships with social enterprises: Venture partnerships. Acumen. Available at https://acumen.org/blog/venturepartnerships/.

Nguyen, H., Stuchtey, M., \& Zils, M. 2014. Remaking the industrial economy. McKinsey Quarterly, Feb.

Norton, T., Parker, S., Zacher, H., \& Ashkanasy, N. 2015. Employee green behavior: A theoretical framework, multilevel review, and future research agenda. Organization \& Environment, 28(1): 103-125.

Novelis. 2017. Novelis sustainability report. Available at http://2gjjon1sdeu33dn mvp1qwsdx.wpengine.netdna-cdn.com/wp-content/uploads/2017/10/NovelisSustainability-Report-2017-ENUS.pdf.

O'Sullivan, D., \& Dooley, L. 2009. Applying innovation. Thousand Oaks, CA: Sage.

OECD. 1997. Proposed guidelines for collecting and interpreting technological innovation data: Oslo manual. Paris: OECD/Eurostat.

Osterwalder, A., \& Pigneur, Y. 2010. Business model generation: A handbook for visionaries, game changers, and challengers. Hoboken, NJ: Wiley.

Phillips, D. 2006. Quality of life: Concept, policy, and practice. London: Routledge. 
Pissourios, I. 2013. An interdisciplinary study on indicators: A comparative review of quality-of-life, macroeconomic, environmental, welfare and sustainability indicators. Ecological Indicators, 34: 420-427.

Porter, M. 1985. Competitive advantage: Creating and sustaining superior performance. New York: The Free Press.

Porter, M., \& Kramer, M. 2011. Creating shared value. Harvard Business Review, Jan.-Feb.

Prahalad, C. 2005. The fortune at the bottom of the pyramid. Delhi, India: Pearson.

Radjou, N., Prabhu, J., \& Ahuja, S. 2012. Jugaad innovation: Think frugal, be flexible, generate breakthrough growth. Hoboken, NJ: Jossey-Bass.

RBC. n.d. RBC future launch. Available at https://www.rbc.com/dms/enterprise/ futurelaunch/index.html.

Reike, D., Vermeulen, W., \& Witjes, S. 2018. The circular economy: New or refurbished as CE 3.0?-Exploring controversies in the conceptualization of the circular economy through a focus on history and resource value retention options. Resources, Conservation, and Recycling, 135: 246-264.

Ries, E. 2011. The lean startup: How today's entrepreneurs use continuous innovation to create radically successful businesses. New York: Crown Publishing.

Rothaermel, F. 2015. PepsiCo's Indra Nooyi: Performance with purpose. In F. Rothaermel, Strategic management: 450-452. New York: McGraw Hill Education.

Rotman, D. 2014. Technology and inequality. MIT Technology Review, Oct. 21.

Schilling, M. 2017. Strategic management of technological innovation. New York: McGraw-Hill.

Stewart, M. 2018. The birth of a new American aristocracy. The Atlantic, June: 49-63. 
Strezov, V., Evans, A., \& Evans, T. 2017. Assessment of the economic, social and environmental dimensions of the indicators for sustainable development. Sustainable Development, 25(3): 242-253.

Sustainable Brands. 2018. Unilever's sustainable living brands delivered $70 \%$ of turnover growth in 2017. Available at https://sustainablebrands.com/read/ business-case/unilever-s-sustainable-living-brands-delivered-70-of-turnovergrowth-in-2017.

Swanson, D. 2008. Top managers as drivers for corporate social responsibility. In A. Crane, D. Matten, A. McWilliams, J. Moon, \& D. S. Siegel (Eds.), The Oxford handbook of corporate social responsibility: 227-248. Oxford: Oxford University Press.

The Economist. 2001. Steel producers: Smeltdown. Oct. 18. Available at https:// www.economist.com/business/2001/10/18/smeltdown.

The Economist. 2013. Free exchange: The humble hero. May 18. Available at https:// www.economist.com/finance-and-economics/2013/05/18/the-humble-hero.

The Economist. 2017. Head in the cloud: What Satya Nadella did at Microsoft. March 16. Available at https://www.economist.com/business/2017/03/16/whatsatya-nadella-did-at-microsoft.

Thiry, G. 2015. Beyond GDP: Conceptual grounds of quantification. The case of the index of economic well-being (IEWB). Social Indicators Research, 121(2): $313-343$.

Thompson, J., \& MacMillan, I. 2010. Business models: Creating new markets and societal wealth. Long Range Planning, 43(2-3): 291-307.

Thorpe, L. 2014. Interface is a carpet-tile revolutionary. The Guardian, May 15. Available at https://www.theguardian.com/sustainable-business/sustainabilitycase-studies-interface-carpet-tile-revolutionary.

Tohidi, H., \& Jabbari, M. 2012. Innovation as a success key for organizations. Procedia Technology, 1: 560-564. 
Tushman, M., \& O'Reilly, C. 1997. Winning through innovation: A practical guide to leading organizational change and renewal. Boston, MA: Harvard Business School Press.

Upson, S. 2018. Tech companies try to retrain the workers they're displacing. Wired, March 16. Available at https://www.wired.com/story/tech-companies-try-toretrain-the-workers-theyre-displacing/.

Walker, S. 2013. Design and spirituality: Material culture for a wisdom economy. Design Issues, 29(3): 89-107.

West, G. 2017. Scale: The universal laws of growth, innovation, sustainability, and the pace of life in organisms, cities, economies, and companies. New York: Penguin.

Worthington, S. 2018. Populist nationalism threatens progress on Sustainable Development Goals. InterAction. Available at https://www.interaction.org/blog/ populist-nationalism-threatens-progress-on-sustainable-development-goals-butngo-community-can-be-the-difference/.

Young, T. 2006. Innovation as the essential ingredient in American economic growth and future survival. In R. Taplin (Ed.), Innovation and business partnering in Japan, Europe, and the United States: 88-103. London: Routledge.

Bernard Arogyaswamy is a Professor of Management in the Madden School of Business at LeMoyne College (Syracuse, New York). He teaches Strategic Management, Global Strategy, Innovation, and Sustainability. He has numerous journal articles on topics as varied as Organizational Culture, Corporate Social Responsibility, and Innovation in countries such as India, China, and Poland. Bernard's most recent publications are on "Energy Sustainability and Pope Francis' Encyclical on Care for our Common Home" (Consilience 18 [2017]), the articulation of a time-based measurement system for social entrepreneurship, and the development of a multilevel system of indicators for sustainability. His current work explores ways in which the sustainability of economic, political, and social systems may be enhanced. 